\title{
PENERAPAN MAGANG KOGNITIF (COGNITIVE APPRENTICESHIP) UNTUK MENGAJARKAN KETERAMPILAN METAKOGNITIF DAN HASIL BELAJAR KOGNITIF SISWA
}

\author{
Dian Anisa Rokhmah Wati ${ }^{1)}$ \\ Tukiran ${ }^{2)}$ \\ Muslimin Ibrahim $^{2)}$ \\ 1) Mahasiswa Pendidikan Sains Pascasarjana Unesa \\ ${ }^{2)}$ Dosen Pendidikan Sains Universitas Negeri Surabaya \\ e-mail:dian.anisa12@gmail.com
}

\begin{abstract}
Abstrak: Tujuan utama penelitian ini adalah untuk mendeskripsikan (1) Hasil belajar kognitif siswa yang diajarkan menggunakan magang kognitif dengan strategi reciprocal teaching (RT), scardamalia and bereiter's $F . W(S B)$, dan schoenfeld problem solving (SPS), (2) Tingkat keterampilan metakognitif siswa yang diajarkan menggunakan magang kognitif dengan strategi RT, SB, dan SPS. Jenis penelitian yang dilakukan adalah experimental research menggunakan static group pretest-postest design yang terdiri dari tiga kelas eksperimen dengan perlakuan yang berbeda-beda. Subjek penelitian yaitu siswa kelas XI IPA SMA Darul Ulum 2 Unggulan BPPT Jombang dengan jumlah masing-masing kelas eksperimen adalah 22 siswa. Instrumen yang digunakan berupa soal tes dan angket. Data hasil belajar kognitif siswa yang diperoleh akan dianalisis dengan anava satu jalur menggunakan SPSS 19 dan data angket akan dideskripsikan. Hasil analisis data menunjukkan terdapat perbedaan hasil belajar kognitif siswa yang diajar menggunakan magang kognitif dengan strategi RT, SB, dan SPS. Tingkat keterampilan metakognitif siswa secara individual mengalami kecendrungan meningkat untuk kelas RT, SB, dan SPS, sedangkan secara rata-rata kelas tingkat keterampilan metakognitif siswa berada pada tingkat 3 yaitu tingkat developing untuk kelas RT, dan SB, sedangkan untuk kelas SPS berada pada tingkat 4 yaitu tingkat ok. Disimpulkan bahwa pembelajaran magang kognitif dengan strategi SPS dapat digunakan untuk mengajarkan keterampilan metakognitif, dengan pendampingan yang lebih maksimal dan disarankan untuk menerapkan strategi RT dan SB pada topik yang memiliki karakteristik yang sesuai yaitu membaca dan menulis.
\end{abstract}

Kata Kunci: Magang Kognitif, Keterampilan Metakognitif, dan Hasil belajar Kognitif

\begin{abstract}
The main aim of this research are to describe (1) cognitive learning outcomes of students who were taught using the cognitive apprenticeship using reciprocal teaching (RT), scardamalia and bereiter's $F . W(S B)$, and schoenfeld problem solving (SPS) strategies and (2) metacognitive skill level of students who are taught using the cognitive apprenticeship with RT, SB, and SPS strategies. This type of research is experimental research using the static group pretest-posttest design consisting of three classes of experiments with different treatments. Research subjects are students of XI IPA 2 SMA Darul Ulum Unggulan BPPT Jombang by the number of each class of experiments is 22 students. Instruments used are in the form of test and questionnaire. Students' cognitive learning outcomes data obtained will be analyzed with one way ANOVA using SPSS 19 and questionnaire data will be described.The result of data analysis revealed that Ho is rejected and Hi is accepted. It means that there was differences in cognitive learning outcomes of students who were taught using the cognitive apprenticeship with RT, SB, and SPS strategies. Metacognitive skill level of individual students experiencing increased tendency for RT, SB, and SPS class, while the average grade of students' metacognitive skills is in grade 3, developing grade for RT and SB class, while grade of students' metacognitive skills is in grade 4, ok grage for SPS class. It can be concluded that the cognitive apprenticeship learning with SPS strategy can be used to teach metacognitive skills with more scaffolding and advised to use RT and SB strategies for suitable characteristics topic (reading and writing).
\end{abstract}

Keywords: Cognitive Apprenticeship, Skills Metacognitive, Cognitive and Learning Outcomes

\section{PENDAHULUAN}

SMA Darul Ulum 2 Unggulan BPPT Jombang (kemudian ditulis dengan SMA DU 2) merupakan salah satu full day school yang berada di bawah naungan yayasan pondok pesantren Darul Ulum Jombang. Sebagai SMA unggulan, SMA DU 2 memiliki standar tersendiri dalam kurikulum sekolahnya dan sebagai SMA yang berada di lingkungan pondok persantren, SMA DU 2 harus mengikuti semua tata aturan yang telah ditetapkan oleh yayasan untuk siswa maupun tenaga pengajar dan seluruh staf-stafnya.

Berdasarkan data penerimaan siswa baru 4 tahun terakhir, siswa SMA DU 2 merupakan siswa yang berasal dari berbagai daerah di Indonesia seperti Tulungagung, Magelang, Palembang, dan Batam, bahkan sebagian besar merupakan siswa yang berasal dari luar kota Jombang, kebanyakan mereka tinggal di asrama-asrama yang berada di lingkungan pondok pesantren dan siswa-siswa tersebut 
selain harus mematuhi tata tertib sekolah, mereka juga mematuhi dan mengikuti semua kegiatan yang ada di asrama seperti sekolah diniyah dan mengaji dengan pembina asrama masing-masing. Siswa SMA DU 2 dituntut mampu mengatur waktunya untuk kegiatan yang begitu banyak sehingga mereka memerlukan suatu keterampilan strategi belajar yang efektif dan belajar bagaimana belajar dalam lingkungan pondok pesantren. Belajar tentang bagaimana belajar ini disebut dengan istilah metakognisi (Woolfolk, 2008).

Menurut Brown (1987), Flavell (1987), Jacobs \& Paris (1987) dalam Schraw (1994), metakognisi dibedakan atas dua komponen besar, yaitu pengetahuan tentang kognisi dan regulasi kognisi. Pengetahuan tentang kognisi terdiri dari tiga subproses yang memfasilitasi adanya refleksi terhadap aspek metakognisi yang mencakup pengetahuan deklaratif (pengetahuan tentang diri sendiri dan strategi), pengetahuan prosedural (pengetahuan tentang bagaimana menggunakan strategi), dan pengetahuan kondisional (pengetahuan tentang kapan dan mengapa menggunakan strategi). Regulasi kognisi terdiri dari lima komponen keterampilan yang memfasilitasi adanya kontrol terhadap aspek belajar yaitu perencanaan, strategi manajemen informasi, monitoring komprehensif, strategi debugging (mengecek dan memperbaiki kesalahan yang ada), dan evaluasi (Artzt \& Armour-Thomas, 1992; Baker, 1989 dalam Schraw, 1994).

Angket MAI (metacognitive awareness inventory) yang telah disebar pada 59 responden dari siswa kelas XI IPA di SMA DU 2 menunjukkan bahwa 27\% siswa berada pada kesadaran metakognisi tingkat 2 (can not really); lalu $55,93 \%$ pada tingkat 3 (developing); $13,56 \%$ pada tingkat 4(ok) dan 3,39\% pada tingkat 5 (super). Terlihat bahwa persentase terbanyak kesadaran metakognisi siswa berada pada tingkat $3(55,93 \%)$. Tingkat 3 ini disebut dengan tingkat developing yang berarti siswa dapat dibantu menuju kesadaran metakognisi jika tergugah atau didukung. Hal ini berarti bahwa siswa kelas XI IPA di SMA DU 2 membutuhkan pendampingan untuk melatih keterampilan metakognitif mereka, sehingga peneliti mencoba mengadaptasi kebiasaan di pondok pesantren yang "sendiko dawuh" dengan titah para kyainya ke pembelajaran di sekolah dengan memilih magang kognitif sebagai cara untuk mengajarkan keterampilan metakognitif dan hasil belajar kognitif siswa dengan menerapkan tiga strategi pembelajaran yang telah sukses diterapkan untuk magang kognitif, yaitu: Palinscar and Brown (RT), Scardamalia and bereiter's procedural facilitation of writing (SB), dan Schoenfeld's method for teaching mathematical problem solving (SPS).

RT merupakan strategi yang digunakan untuk meningkatkan kemampuan membaca dengan langkah- langkah meringkas, membuat pertanyaan, mengklarifikasi dan memprediksi. SB adalah strategi untuk meningkatkan kemampuan menulis dengan langkah-langkah prencanaan yang meliputi (1) New Idea (Penulisan ide baru), (2) Improve (Pengembangan ide-ide), (3) Elaborate (Perincian ide-ide), (4) Goals (Pengidentifikasian tujuan), dan (5) Put it together (Peletakan ide-ide pada satu kesatuan yang tepat), dan revisi. SPS adalah strategi untuk problem solving yang meliputi langkah-langkah (1) analisis problem, (2) eksplorasi, (3) design, (4) implementasi, dan (5) verifikasi. (Collins, Brown, and Newman, 1987).

Kemampuan membaca, menulis dan problem solving merupakan kemampuan yang dibutuhkan untuk pencapaian KD 4.6 yang berbunyi memprediksi terbentuknya endapan dari suatu reaksi berdasarkan prinsip kelarutan dan hasil kali kelarutan. Siswa yang memiliki kemampuan membaca baik, akan mudah menyerap informasi sehingga lebih mudah memahami materi dan siswa akan lebih menguasai materi jika mereka juga memiliki kemampuan menulis. Menuliskan kembali informasi yang mereka dapat membuat informasi tersebut tersimpan di memori jangka panjang. Kemampuan problem solving merupakan kemampuan siswa menganalisis suatu problem, mengumpulkan informasiinformasi penting tentang problem tersebut sehingga bisa merencanakan langkah-langkah penyelesaiannya dengan tepat, dan hal tersebut akan sangat membantu siswa dalam menguasai materi (Shoenfeld, 1985). Kemampuan membaca, menulis, dan problem solving akan meningkatkan hasil belajar kognitif siswa, sehingga dalam penelitian ini akan diterapkan tiga strategi tersebut yaitu RT, SB, dan SPS.

Beberapa masalah yang akan dijawab oleh peneliti adalah sebagai berikut: (1) Apakah ada perbedaan hasil belajar kognitif siswa yang diajarkan menggunakan magang kognitif dengan strategi berbeda yaitu RT, SB, dan SPS?, (2) Bagaimanakah tingkat keterampilan metakognitif siswa yang diajarkan menggunakan magang kognitif dengan strategi berbeda yaitu RT, SB, dan SPS?. Penelitian ini juga akan menjawab beberapa pertanyaan untuk membantu menjawab rumusan masalah pertama, sebagai berikut: (1) Bagaimanakah keterlaksanaan pembelajaran magang kognitif dengan strategi RT, SB, dan SPS? dan (2) Bagaimana respon siswa terhadap pembelajaran magang kognitif dengan strategi berbeda yaitu RT, SB, dan SPS? Hipotesis penelitian ini adalah strategi SPS merupakan strategi yang paling sesuai untuk mengajarkan keterampilan metakognitif dan hasil belajar kognitif siswa pada topik kelarutan dan konstanta hasil kali kelarutan. Ho tidak ada beda keterampilan metakognitif dan hasil belajar kognitif siswa yang diajar menggunakan strategi magang kognitif RT, SB, dan SPS. 


\section{METODE}

Jenis penelitian ini adalah eksperimental research dengan design penelitian static group pretest-postest sehingga didapatkan notasi sebagai berikut:

Tabel 1. Design Penelitian

\begin{tabular}{|c|c|c|c|}
\hline Group 1 & 01 & RT & 02 \\
\hline Group 2 & 01 & SB & 02 \\
\hline Group 3 & 01 & SPS & 02 \\
\hline
\end{tabular}

Sumber: Fraenkel (2009) dan dimodifikasi oleh peneliti

Keterangan:

$01=$ pretest

$02=$ postest

Populasi penelitian ini adalah siswa jurusan IPA di SMA Darul Ulum 2 Unggulan BPPT Jombang. Sampel dalam penelitian ini adalah siswa kelas XI IPA 5, IPA 6, dan IPA 7 yang ditentukan melalui proses pengacakan kelas.

Instrumen yang digunakan dalam penelitian ini adalah lembar observasi, angket MSI (metacognitive skill inventory), angket respon siswa, TPK untuk tes hasil belajar kognitif, dan lembar catatan guru. Teknik analisis data yang digunakan adalah dokumentasi, observasi, pemberian angket dan pemberian tes. Data yang diperoleh dari observasi dan angket akan dianalisis secara diskriptif kuantitatif. Data tes hasil belajar kognitif akan dianalisis menggunaka teknik one way anova dan analisis lanjutan tukey HSD dengan menggunakan program SPSS 19.

\section{HASIL DAN PEMBAHASAN}

Hasil keterlaksanaan RPP masing-masing strategi adalah $100 \%$, artinya setiap langkah dalam strategi terlaksana dengan baik sesuai dengan perencanaan awal.

\section{Hasil Belajar Kognitif Siswa}

Hasil analisis one way anova terhadap hasil belajar kognitif siswa menunjukkan bahwa Ho ditolak artinya ada beda hasil belajar kognitif siswa yang diajar menggunakan strategi magang kognitif RT, SB, dan SPS. Hasil tersebut dapat diliha pada tabel berikut:

Tabe1 2. Rata-Rata Niläi Pretest (ö1)-Postest (02) Siswa

\begin{tabular}{|c|c|c|c|c|c|c|}
\hline & \multicolumn{2}{|l|}{ RT } & SB & \multicolumn{2}{|l|}{ SPS } \\
\hline & & 01 & 02 & 01 & 01 & 02 \\
\hline \multicolumn{2}{|l|}{ Nilai } & 27 & 43 & 26 & 34 & 76 \\
\hline \multicolumn{2}{|c|}{ Perubahan } & \multicolumn{2}{|c|}{16} & 31 & \multicolumn{2}{|l|}{42} \\
\hline \multicolumn{7}{|c|}{ Tabe1 3. Hasil Analisis C } \\
\hline $\begin{array}{l}\text { Jenis } \\
\text { strategi }\end{array}$ & $\mathbf{N}$ & & Mean & SD & $\mathbf{F}$ & $\begin{array}{l}\text { p- } \\
\text { value }\end{array}$ \\
\hline RT & \multirow{3}{*}{\multicolumn{2}{|c|}{22}} & 43,41 & 18,073 & \multirow[t]{3}{*}{16,416} & \multirow{3}{*}{0,000} \\
\hline SB & & & 57,64 & 22,415 & & \\
\hline SPS & & & 75,82 & 15,227 & & \\
\hline \multicolumn{7}{|c|}{$\begin{array}{l}\text { Hasil uji lanjutan dapat dilihat pada tabel berikut: } \\
\text { Tabel } 4 \text { Hasil Uji Tukey HSD }\end{array}$} \\
\hline \multicolumn{3}{|c|}{$\begin{array}{l}\text { Jenis Magang } \\
\text { Kognitif }\end{array}$} & \multicolumn{2}{|c|}{ p-value } & \multicolumn{2}{|c|}{ Simpulan } \\
\hline \multicolumn{3}{|c|}{ RT vs SB } & \multicolumn{2}{|c|}{0,038} & \multicolumn{2}{|c|}{$\begin{array}{l}\text { Berbeda } \\
\text { Bermakna }\end{array}$} \\
\hline \multicolumn{3}{|c|}{ RT vs SPS } & \multicolumn{2}{|c|}{0,000} & \multicolumn{2}{|c|}{$\begin{array}{c}\text { Berbeda } \\
\text { Bermakna }\end{array}$} \\
\hline \multicolumn{3}{|c|}{ SB vs SPS } & \multicolumn{2}{|c|}{0,006} & \multicolumn{2}{|c|}{$\begin{array}{l}\text { Berbeda } \\
\text { Bermakna }\end{array}$} \\
\hline
\end{tabular}

Data di Tabel 2 menunjukkan bahwa rata-rata hasil belajar siswa tertinggi berada pada jenis strategi SPS. Hal ini menunjukkan bahwa siswa di kelas SPS memperoleh nilai yang lebih tinggi dibanding dua kelas lainnya sehingga dapat dikatakan bahwa strategi SPS lebih sesuai untuk pembelajaran topik kelarutan dan konstanta hasil kali kelarutan dengan karakteristik KD yang melibatkan banyak penyelesaian soal hitungan. Siswa di kelas RT dan SB melakukan langkah-langkah penyelesaian soal yang lebih singkat dibanding dengan strategi SPS, sehingga proses pengalaman belajar siswa juga lebih sedikit. sehingga pemahaman siswa juga lebih sedikit. Hal ini senada dengan teori pemrosesan informasi, bahwa siswa harus mengalami sendiri dan terlibat lebih mendalam dalam proses mental yang terjadi sehingga akan membantu mereka memproses informasi yang telah mereka dapat yang berupa konsep, prinsip, atau aturan dan bagaimana menggunakannya serta keterampilan memecahkan masalah dan strategi belajarnya dari memori jangka pendek ke memori jangka panjang (Slavin, 2006).

\section{Keterampilan Metakognitif Siswa}

Hasil penelitian selanjutnya adalah tentang keterampilan metakognitif siswa yang dapat dilihat pada tabel berikut:

Tabel 5. Hasil Keterampilan Metakognitif Sisw

\begin{tabular}{|l|c|c|c|c|c|c|}
\hline \multirow{2}{*}{$\begin{array}{c}\text { Tingkat } \\
\text { Keretampilan } \\
\text { Metakognitif }\end{array}$} & \multicolumn{6}{|c|}{ Rumlah Siswa } \\
\cline { 2 - 8 } Not yet & $\mathbf{0 1}$ & $\mathbf{0 2}$ & $\mathbf{0 1}$ & $\mathbf{0 2}$ & $\mathbf{0 1}$ & $\mathbf{0 2}$ \\
\hline At risk & 0 & 0 & 0 & 0 & 0 & 0 \\
\hline Developing & 0 & 0 & 0 & 0 & 0 & 0 \\
\hline Ok & 6 & 2 & 4 & 4 & 5 & 0 \\
\hline Super & 13 & 12 & 12 & 10 & 14 & 6 \\
\hline
\end{tabular}

Jumlah siswa di Tabel 5 menunjukkan bahwa terjadi tren peningkatan tingkat ketrampilan metakognitif di setiap kelas eksperimen secara individu.

Tabel 6. Tingkat Keterampilan Metakognitif Rata- Rata Siswa

\begin{tabular}{|c|c|c|}
\hline Jenis Strategi & \multicolumn{2}{|l|}{$\begin{array}{l}\text { Tingkat Keterampilan } \\
\text { Metakognitif }\end{array}$} \\
\cline { 2 - 3 } & $\begin{array}{l}\text { Sebelum } \\
\text { Perlakuan }\end{array}$ & $\begin{array}{l}\text { Setelah } \\
\text { Perlakuan }\end{array}$ \\
\hline RT & 3 & 3 \\
\hline SB & 3 & 3 \\
\hline SPS & 3 & 4 \\
\hline
\end{tabular}

Peningkatan rata-rata keterampilan metakognitif siswa yang terlihat pada Tabel 6 hanya terjadi di kelas yang diajar dengan strategi SPS dari tingkat 3 (developing), tingkat dimana siswa dapat dibantu menuju terampil dalam melakukan keterampilan metakognitif (prencanaan, monitoring, dan evaluasi) untuk menyelesaikan soal kimia 
dengan diberikan dukungan dan pendampingan ke tingkat 4 (ok), tingkat dimana siswa dapat melakukan keterampilan metakognitif (dapat melakukan perencanaan dan menerapkannya, serta dapat memonitor kinerjanya dan mengevaluasi hasil kerjanya) dalam menyelesaikan soal kimia.

Pembelajaran magang kognitif dengan strategi SPS ini memiliki langkah-langkah penyelesaian soal yang dapat digunakan untuk melatihkan keterampilan metakognitif. Di kelas SPS keterampilan metakognitif perencanaan ada di langkah analisis yang memiliki karakter sama dengan kegiatan meringkas dan membuat pertanyaan pada kelas RT dan membuat garis besar penyelesaian soal yang tidak dilakukan di kelas RT dan SB. Kegiatan menuliskan informasi dalam ringkasan dan membuat pertanyaan ini akan membantu siswa dalam menentukan langkah-langkah berikutnya untuk menyelesaiakn soal. Paris et al (1984) dalam King (1992a) dalam Slavin (2006) menemukan bahwa penguasaan siswa akan lebih baik jika mereka diajarkan untuk bertanya pada diri mereka sendiri. Dan kegiatan membuat ringkasan tentang informasi yang diketahui dapat membantu siswa menentukan informasi mana yang benar-benar penting dan yang tidak, sedangkan kegiatan membuat garis besar penyelesaian soal akan membantu siswa lebih sistematis (Slavin, 2006).

Keterampilan metakognitif selanjutnya adalah monitoring yang dalam kelas SPS ini ada pada sebagian tahap design, eksplorasi, implementasi, dan verifikasi yang beberapa langkahnya memiliki karakteristik yang sama dengan SB yaitu pengecekan ulang informasi dan penentuan waktu. Kegiatan monitoring merupakan kegiatan dimana siswa memonitor kinerjanya atau kognitifnya. Melakukan klarifikasi terhadap kata-kata yang mereka anggap sulit dan mengecek kembali informasi yang telah mereka tulis berarti siswa telah memonitor perkembangan kognitifnya dalam menghubungkan pengetahuan masa lalu yang sesuai dengan kondisi yang dihadapi saat ini, seperti yang dikatakan oleh Arend (1997) bahwa pengetahuan masa lalu yang disebut perior knowledge siswa dapat mengontrol kemungkinan pembelajaran yang baru, pengetahuan baru yang spesifik seperti fakta, konsep, dan keterampilan tidak dapat dipelajari sampai disediakan kondisi yang berhubungan dengan pengetahuan masa lalu yang sesuai. Dan dengan memperkirakan waktu yang akan mereka gunakan, siswa telah belajar mengukur keterampilan mereka sendiri dan bagaimana strategi yang akan mereka gunakan untuk memenuhi tenggat waktu tersebut dalam menyelesaikan soal. Menurut Nur (2008) dalam keterampilan metakognitif siswa dapat diajarkan strategi-strategi untuk menilai pemahaman mereka sendiri, menghitung berapa waktu yang mereka perlukan, dan memilih rencana yang efektif untuk belajar atau memecahkan masalah.

Keterampilan metakognitif terakhir yang dilatihkan dalam penelitian ini adalah evaluasi yang di kelas SPS keterampilan ini diajarkan di tahap verifikasi ketikaka siswa menuliskan reward yang diinginkan dan membuat kesimpulan. Diajarkannya keterampilan metakognitif ini memungkinkan siswa untuk berkembang menjadi pebelajar yang mandiri serta menjadi penilai atas pikiran dan pembelajarannya sendiri, seperti yang dikatakan oleh Zimmerman (2001) dalam Shannon (2008) bahwa self regulated learner adalah siswa yang mampu menghasilkan pemikiran sendiri dan tingkah laku yang sistematis berorientasi pada tujuan pembelajaran, dan untuk mencapai itu siswa harus sadar akan proses yang mereka lalui, dan menjadi termotivasi untuk aktif dalam proses pembelajaran.

\section{Respon Siswa}

Respon Siswa terhadap strategi pembelajaran yangditerapkan dapat dilihat pada tabel berikut:

Tabel 7. Rekapitulasi Persentase(\%) Respon Siswa

\begin{tabular}{|c|c|c|c|}
\hline \multirow{2}{*}{ Respon } & \multicolumn{3}{|c|}{ Strategi Magang kognitif } \\
\cline { 2 - 4 } & RT & SB & SPS \\
\hline Senang & 73,86 & 82,95 & 81,82 \\
\hline Baru & 82,93 & 81,82 & 73,86 \\
\hline Jelas & 75,00 & 82,95 & 77,27 \\
\hline Tertarik & 100 & 100 & 90,91 \\
\hline
\end{tabular}

Persentase yang rendah pada kesenangan siswa di kelas RT ini bisa dihubungkan dengan rendahnya hasil belajar mereka yang memiliki rata-rata peningkatan hanya 16 dibandingkan dengan kelas SB dan SPS yang memiliki rata-rata peningkatan 31 dan 42 . Hal ini juga berhubungan dengan keterlibatan siswa dalam proses mental selama pembelajaran berlangsung, di kelas RT ini siswa hanya mengalami 4 langkah proses penyelesaian soal, dan itu jauh lebih sedikit jika dibandingkan dengan siswa pada kelas SB yang mengalami 11 langkah proses dan 13 langkah pada siswa di kelas SPS. Semakin banyak kerja mental yang dilakukan akan mebantu siswa memproses informasi dalam memori jangka pendek dan selanjutnya menempatkannya ke dalam memori jangka panjang (Slavin, 2006), sehingga ini berpengaruh terhadap hasil belajar mereka. Nilai yang diperoleh siswa dalam tes hasil belajar merupakan salah satu konsekuensi yang tidak menyenangkan bagi siswa. Menurut B.F Skinner dalam Slavin (2006) nilai merupakan salah satu penguatan simbolik dan dengan nilai yang rendah membuat siswa kehilangan penguatan sehingga merespon tidak senang terhadap strategi tersebut dan juga materi yang sedang diajarkan, Sehingga respon kesenangan di kelas RT ini lebih kecil dibanding di kelas SB dan SPS.

Respon siswa selanjutnya adalah respon terhadap kebaruan yang meliputi kebaruan materi pelajaran, LKS, 
aktivitas pembelajaran maupun cara guru mengajar. Di kelas RT 82, 93\% siswa menyatakan bahwa pembelajaran ini baru bagi mereka. Di kelas SB sebanyak $81,82 \%$ dan di kelas SPS 73,86\%. Kebaruan ini berhubungan dengan apakah siswa pernah mendapatkan pengalaman belajar seperti yang ada di langkah-langkah masing-masing strategi ataukah belum. Untuk materi pelajaran semua siswa menyatakan baru, karena memang mereka belum pernah menerima materi tersebut. Sebagian besar siswa juga sepakat bahwa LKS yang digunakan dalam tiap strategi merupakan LKS yang belum pernah mereka temui sebelumnya karena memang LKS tersebut dibuat sesuai dengan strategi-strategi yang sebelumnya banyak diterapkan di pelajaran bahasa kecuali SPS. Respon kebaruan yang rendah di kelas SPS dibandingkan kelas RT dan SB ini karena SPS pada dasarnya adalah strategi pemecahan masalah yang sering diterapkan pada pelajaran matematika dan sains dengan sedikit modifikasi oleh peneliti untuk melatihkan keterampilan metakognitif, dimungkinkan siswa sering menjumpai strategi yang mirip ketika mereka menyelesaikan soal-soal matematika dan bidang sains lainnya.

Respon siswa berikutnya adalah pada kejelasan yang juga meliputi materi ajar, LKS, aktivitas belajar, dan cara guru mengajar. Rata-rata total kejelasan di kelas RT adalah 75\%, SB 82,95\%, dan SPS 77,27\%. Di kelas RT sumbangan ketidak jelasan adalah dari LKS, hal ini dapat dilihat dari persentase yang hanya 59,09\% siswa yang memilih jelas, langkah-langkah dalam LKS RT mereka anggap tidak jelas karena memang lebih cocok untuk materi dengan bacaan lebih dominan. Pada kelas SPS sumbangan persentase ketidakjelasan juga berasal dari LKS yaitu hanya $54,55 \%$ siswa yang menyatakan jelas. Langkahlangkah dalam LKS SPS mereka anggap terlalu banyak sehingga dinyatakan sebagai ketidakjelasan. Langkah- langkah dalam LKS tersebut dibuat berdasarkan langkah-langkah yang ada pada masing-masing strategi dengan proses yang panjang untuk menyelesaikan sebuah soal dan bagi siswa tentusaja proses tersebut kurang jelas karena ini hal yang baru bagi mereka, sehingga siswa masih beradaptasi. Penanggulangan yang dilakukan oleh guru untuk mengurangi ketidak jelasan ini adalah dengan adanya aktor guru yang akan berperan sebagai model di kelas RT, di kelas SB dan SPS juga ada minimal satu orang siswa yang memiliki kemampuan lebih di bidang kimia sehingga akan membantu anggota kelompok yang lain. Menurut teori pembelajaran sosial bahwa model yang usianya sama dengan siswa cenderung efektif (Schunk dan Hanson, 1985 dalam Slavin 2006), sehingga harus dipastikan model benar-benar mamahami materi dan cara kerja penyelesaian soal dengan langkah-langkah tersebut.

\section{PENUTUP}

\section{Simpulan}

Berdasarkan pembahasan dapat disimpulkan bahwa:

1. Pembelajaran magang kognitif dengan strategi RT, SB, dan SPS terlaksana $100 \%$ dengan.

2. Tingkat keterampilan metakognitif siswa yang diajarkan menggunakan magang kognitif dengan strategi berbeda yaitu RT, SB, dan SPS berada pada tingkat 3 yaitu tingkat developing untuk siswa di kelas RT dan SB, dan untuk siswa di kelas SPS berada pada tingkat 4 yaitu tingkat ok.

3. Respon siswa terhadap strategi RT, SB, dan SPS adalah bagus dengan rata-rata persentase $82,95 \%$ di kelas RT, $86,93 \%$ di kelas SB, dan $80,97 \%$ di kelas SPS.

\section{Saran}

Beberapa hal yang disarankan oleh peneliti bedasarkan hasil penelitian dan pembahasan adalah sebagai berikut:

1. Pembelajaran magang kognitif dengan strategi RT dan SB sebaiknya diterapkan pada KD yang memiliki karakteristik yang sesuai yaitu untuk kemampuan membaca dan menulis seperti kimia unsur dan struktur atom.

2. Diberikan bimbingan dan pendampingan yang lebih pada siswa ketika mereka mencoba menyelesaikan soal dengan masing-masing strategi, misalnya dengan lesson study atau team teaching yang memungkinkan lebih dari satu guru terlibat dalam pembelajaran.

3. Diadakan pelatihan terlebih dahulu pada siswa yang akan menjadi model/ ahli yang akan ditempatkan pada tiap kelompok sehingga mereka memiliki keterampilan yang diinginkan oleh guru sebelum terjun ke tiap-tiap kelompok agar pendampingan menjadi lebih maksimal.

4. Strategi SPS ini dapat diujicobakan kembali pada topik lain yang memiliki karakteristik mirip dengan topik kelarutan dan konstanta hasil kelarutan, misalnya laju reaksi atau stoikiometri untuk mengetahui lebih lanjut kegunaannya dalam mengajarkan keterampilan metakognitif.

\section{DAFTAR PUSTAKA}

Anderson and Krathwohl, 2001. A Taxomony for Learning, Teaching, and Assessing: A Revision of Bloom's Taxonomy of educational Objectives. United State: Addision Wesley Longman.Inc

Arend, Richard I. 1997. Clasroom Instruction and management. United State of America: McGraw Hill Companies.Inc 
Besral. 2010. Pengolahan dan Analisis Data Menggunakan SPSS, FKM UI

Brady, James E. 2012. Chemistry: the Molecular nature of Matter 6th ed. United State: John Wiley \& Sons, Inc.

Collins, Brown, and Newman. 1987. Cognitive Apprentisechip: Teaching the Craft of Reading, Writing, and Mathematics. Massacusetts: Bolt Beranek and Newman Inc.

Creswell, John W. 2008. Educational Research: Planning, Conducting, and Evaluating Quantitative and Qualitative Research Third Edition. New Jersey: Pearson Prentice Hall.

Dennen, Vanessa Paz. 2003. Cognitive Apprenticeship in Educational Practice: research on Scaffolding, Modeling, Mentoring, and Coaching as Instructional Strategies. Florida state University, No. 31, pp. 813828

Dickey, Michele D. 2007. "Integrating Cognitive Apprenticeship Methods in a Web-based Educational technology Course for P-12 Teacher Education". Elsevier Computer and Education Journal. Vol 51, pp. 506-518.

Depdiknas. 2006. Standar Kompetensi Mata Pelajaran Kimia untuk SMA. Jakarta: Depdiknas

Dwi 2012. Tetapan Dielektrik Beberapa Pelarut. http;//dwijo.blogspot.com/2012/02/macam-macam- pelarut.html (diakses pada juni 2012)

Fraenkel, Jack R. 2009. How to Design and Evaluate Research in Education-7th ed. Newyork; McGrawHill Companies.Inc.

Ghefaili, Aziz. 2003. "Cognitive Apprenticeship, Technology, and the Contextualization of Learning Environment". Journal of Educational computing, Design \& Online Learning. Vol 4, pp. 1-27.

Gredler, Margaret E. 2009. Learning and Instruction. New Jersey: Upper Saddle River

Hamalik. 2005. Proses Belajar Mengajar. Jakarta: PT Bumi Aksara.

Hansey, Jane M and Dianne J.Connors. 2003. "Reciprocal Teaching Action Research, the Reading Teacher". Proquest Education Journal. Vol. 57 No. 3, pp. 224-232

Ibrahim, Muslimin, 2005, Asesmen Berkelanjutan. Surabaya: Unesa

Keenan, Charles W., Kleinfelter, Donald C. and Wood, Jesse.

H. 1984. Ilmu Kimia Untuk Universitas Edisi Ke Enam. Terjemahan Aloysius Hadyana Pudjaatmaka. Jakarta: Erlangga.

Lina, dkk. 2012. Chemistry Workbook XI. Jombang: SMA Darul Ulum 2 Unggulan BPPT RSBI

Manku G S. 2002. The teoretical principles of inorganic chemistry. New Delhi: Tata McGraw-Hill

Myers, Pamela Ann. 2005. "The Princess Story Teller, Clara Clirifier, Quincy Questioner, nad the Wizard. Reciprocal Teaching Adapted for Kindergarten Students. The Reading Teacher". Proquest Education Journal. Vol. 59 No.4, pp. 314-324.

Nbina, Jacobson B and B. Vico. 2010. "Effect on Instruction in Metacognitive Self Assessment Strategy on Chemistry Students Self-efficacy and Achievement". Port Harcourt University, Academia Arena, Vol. 2 No. 8, pp. 34-43

Nur, Mohamad dan Prima Retno W. 2008. Pengajaran Berpusat Kepada Siswa dan Pendekatan Konstruktivis dalam Pengajaran. Surabaya: Unesa PSMS

Nur, Mohamad, dan Prima Retno W. 2008. Teori-Teori Pembelajaran Kognitif. Surabaya: Unesa PSMS

Palinscar \& Brown. 1984. "Reciprocal Teaching of Comprehension-Fostering and ComprehensionMonitoring Activities". Cognition and Instruction Lawrence Erlbaum Associates. Vol. I No.2, pp. 117-175.

Panaoura. A, et al., 2003. "Young Pupils Metacognitive Ability in Mathematics". European Research in Mathematics Education. Vol 3, pp. 1-9

Parno. 2009. Disertasi: Pengaruh Pembelajaran Think-Pair Share dengan Strategi Self Explanation pada Kemampuan Akademik Berbeda terhadap Kesadaran Metakognisis, Kemampuan Berfikir Kritis, dan Penguasaan Materi Fisika Sekolah. Surabaya: Unesa.

Pulmones, Richard. No year. "Learning Chemistry in a Metacognitive Environment". The Asia Pacific Education Researcher, Vol. 16 No. 2, pp. 165-183.

Raharjo, Sentot Budi.2012. Kimia Berbasis Eksperimen untuk Kelas XI SMA dan MA 2. Solo: Tiga Serangkai. Riduwan. 2002. Skala Pengukuran Variabel-Variabel

Penelitian. Bandung: Alfabeta Schoenfeld, Alan H. 1985. Mathematical Problem Solving. London. Academic Press Inc.

Schraw, Gregory \& Dennison. 1994. "Assesing Metacognitive Awareness". Contemporary Educational Psycology,. Vol. 19, pp. 460-475.

Shannon, Steven V. 2008. "Using Metacognitive Strategies and Learning Styles to Create Self Directed Learner". Institute for Learning Styles Journal. Vol. 1, pp. 14-28.

Slavin, Robert E. 2000. Educational Psycology: Theory and Practice 6th Edition. United State of America: Allyn\&Bacon.

Slavin, Robert E. 2006. Educational Psycology: Theory and Practice Eight Edition. United State of America: Allyn\&Bacon. 